\title{
Expression of NMDA receptor subunits in human blood lymphocytes: A peripheral biomarker in online computer game addiction
}

\author{
MITRA-SADAT SADAT-SHIRAZI ${ }^{1,2}$, NASIM VOUSOOGHI $^{1,2,3} *$, BENTOLHODA ALIZADEH $^{4}$, SEYED MOHAMMAD MAKKI $^{5}$, \\ SEYED ZEINOLABEDIN ZAREI ${ }^{6}$, SHAHRZAD NAZARI ${ }^{2}$ and MOHAMMAD REZA ZARRINDAST ${ }^{2,7,8,9}$

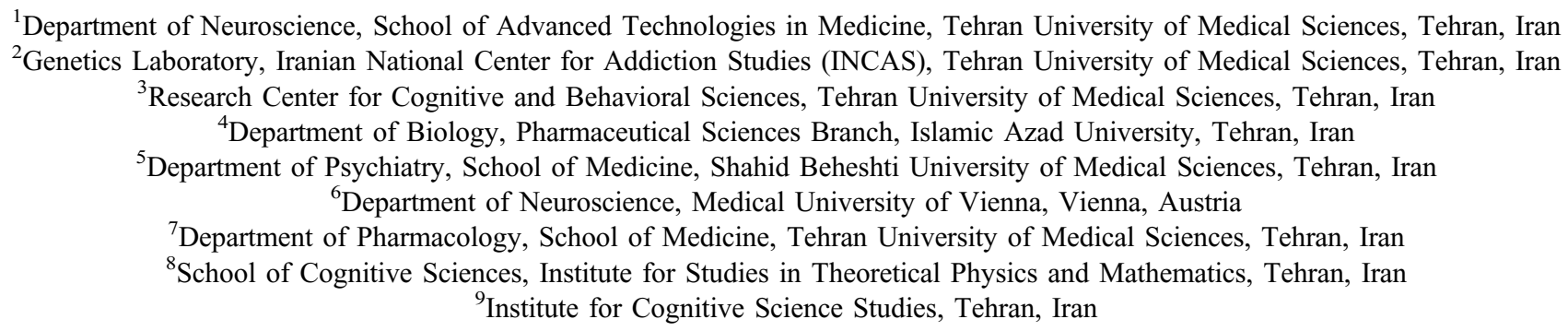

(Received: February 14, 2017; revised manuscript received: February 9, 2018; accepted: March 30, 2018)

\begin{abstract}
Background and aims: Repeated performance of some behaviors such as playing computer games could result in addiction. The NMDA receptor is critically involved in the development of behavioral and drug addictions. It has been claimed that the expression level of neurotransmitter receptors in the brain may be reflected in peripheral blood lymphocytes (PBLs). Methods: Here, using a real-time PCR method, we have investigated the mRNA expression of GluN2A, GluN2D, GluN3A, and GluN3B subunits of the NMDA receptor in PBLs of male online computer game addicts $(n=25)$ in comparison with normal subjects $(n=26)$. Results: Expression levels of GluN2A, GluN2D, and GluN3B subunits were not statistically different between game addicts and the control group. However, the mRNA expression of the GluN3A subunit was downregulated in PBLs of game addicts. Discussion and conclusions: Transcriptional levels of GluN2A and GluN2D subunits in online computer game addicts are similar to our previously reported data of opioid addiction and are not different from the control group. However, unlike our earlier finding of drug addiction, the mRNA expression levels of GluN3A and GluN3B subunits in PBLs of game addicts are reduced and unchanged, respectively, compared with control subjects. It seems that the downregulated state of the GluN3A subunit of NMDA receptor in online computer game addicts is a finding that deserves more studies in the future to see whether it can serve as a peripheral biomarker in addiction studies, where the researcher wants to rule out the confusing effects of abused drugs.
\end{abstract}

Keywords: online computer game addiction, lymphocyte, NMDA receptor, mRNA expression

\section{INTRODUCTION}

Behavioral addictions are disorders comparable with substance addiction, but with a behavioral core other than consumption of a psychoactive drug. Several behavioral addictions have been described, such as compulsive buying, pathological gambling, kleptomania, and sexual addiction (Jorgenson, Hsiao, \& Yen, 2016). A behavioral addiction that has attracted society's attention is computer game addiction, which is described as an intense and uncontrollable desire for playing computer games and excessive involvement in this type of activity, despite awareness of adverse outcomes, such as critical interference with a person's social and personal daily life. People who are addicted to this behavior are ready to ignore almost all other aspects of life to be able to play computer games as much as possible, which would ultimately make the person play $24 \mathrm{hr} / 7$ days of the week (Ustinavičiene et al., 2016).

Glutamate, the main excitatory neurotransmitter in the brain, is a major component of the addiction phenomenon. The neurotransmitter could be extensively found in many parts of the brain, particularly the mesocorticolimbic pathway, which is well known as the reward pathway (Spencer, Scofield, \& Kalivas, 2016). The core of the pathway is made of dopaminergic neurons that originate in the ventral tegmental area and project mainly to the nucleus accumbens and also to other parts, such as the prefrontal cortex (PFC)

* Corresponding author: Nasim Vousooghi, Pharm D, PhD; Department of Neuroscience, School of Advanced Technologies in Medicine, Tehran University of Medical Sciences, PO Box 1417755469, Tehran, Iran; Phone: +98 218899 1118; Fax: +98 21 8899 1117; E-mail: n-vousooghi@tums.ac.ir

This is an open-access article distributed under the terms of the Creative Commons Attribution-NonCommercial 4.0 International License, which permits unrestricted use, distribution, and reproduction in any medium for non-commercial purposes, provided the original author and source are credited, a link to the CC License is provided, and changes - if any - are indicated. 
and amygdala. Consumption of addictive drugs or performance of addictive behaviors stimulates reward pathway and ultimately increases the concentration of dopamine in the nucleus accumbens (Cooper, Robison, \& MazeiRobison, 2017). In addition to dopaminergic neurons, nucleus accumbens also receives glutamatergic information from regions, such as the thalamus, hippocampus, amygdala, and frontal cortex, which makes glutamate to interact with dopamine in the modulation of reward and reinforcement and development of addictive behaviors (Kalivas, 2009; Tzschentke \& Schmidt, 2003).

Glutamate exerts its effects by two types of receptors, namely ionotropic and metabotropic. N-methyl-D-aspartate (NMDA) receptor as a member of ionotropic glutamate receptors is a tetramer made up of three different subunit classes: GluN1, GluN2 (GluN2A-D), and GluN3 (GluN3A and $\mathrm{B}$ ), which may be composed as GluN1/GluN2 or GluN1/GluN2/GluN3. The main characteristic of NMDA receptors is its high permeability to calcium, which could lead to excitatory postsynaptic currents (Glasgow, Siegler Retchless, \& Johnson, 2015). However, incorporation of GluN3 subunits in the structure of NMDA receptor reduces calcium current through the receptor channel and suppresses the excitatory effect of NMDA receptor (Cavara \& Hollmann, 2008; Pérez-Otaño, Larsen, \& Wesseling, 2016).

It has been reported that the expression of NMDA receptors is not limited to the neural cells; other cell types, such as lymphocytes, may also express NMDA receptors (Boldyrev et al., 2004). Stimulation of NMDA receptors in lymphocytes affects the performance of these cells since it has been shown that the application of NMDA receptor antagonists is able to inhibit T-cell proliferation by preventing their activation (Miglio, Varsaldi, \& Lombardi, 2005). Studies have revealed that different subunits of the NMDA receptor, including GluN1, GluN2A, GluN2B, GluN2D, GluN3A, and GluN3B, are expressed in human peripheral blood lymphocytes (PBLs), while GluN2C expression in these cells is uncertain (Biermann, Bonsch, Reulbach, Kornhuber, \& Bleich, 2007; Miglio et al., 2005; Roozafzoon et al., 2010; Sedaghati et al., 2010).

The expression pattern of NMDA receptor subunits in various regions of the brain is not a static phenomenon; indeed, several disorders including addiction may alter the expression levels of these subunits in the brain (Bajo, Crawford, Roberto, Madamba, \& Siggins, 2006). For example, animal studies have shown that opioid addiction may upregulate the mRNA expression level of GluN1 subunits in the rat nucleus raphe magnus, medial thalamus (Zhu, Brodsky, Gorman, \& Inturrisi, 2003), locus coeruleus, hypothalamic paraventricular nucleus (Zhu et al., 1999), and amygdala (Turchan, Maj, \& Przewlocka, 2003). In addition, in a postmortem study, it was found that GluN2B subunit is upregulated in the hippocampus in both alcoholics and cocaine addicts, whereas GluN2D was upregulated in alcoholics and downregulated in cocaine addicts compared with controls (Enoch et al., 2014). In animal studies, it has been shown that the mRNA expression level of GluN1 subunit, but not GluN2 or GluN3, is increased in basolateral amygdala samples from chronic ethanol-exposed rats (Floyd, Jung, \& McCool, 2003). Furthermore, chronic nicotine treatment in mice has revealed no effect on the expression level of GluN1 and GluN2B subunits in the PFC and midbrain. However, expression of GluN2A in PFC was reduced by the same treatment (Pistillo et al., 2016). Despite the mentioned studies, the human data regarding the expression changes of NMDA receptor subunits in addictive behaviors like playing online computer games are much more limited. One main reason is the present impossibility of doing direct experiments in the living brain of addicted individuals. Thus, we may have to choose an alternative way, such as using the concept of "peripheral marker hypothesis." According to the hypothesis, the expression level of neurotransmitter receptors in the brain is correlated with the expression changes of these receptors in PBLs. For example, it has been shown that the augmented activation of central dopaminergic neurotransmission in schizophrenic patients is reflected in their PBLs in the form of the upregulation of the expression level of dopamine receptors in these cells (Carlsson, Waters, \& Carlsson, 1999; Ilani et al., 2001; Zvara et al., 2005). In contrast, in Parkinson's disease, which is associated with decreased neurotransmission of dopamine in the striatum, the level of expression of dopamine receptors is also reduced in PBLs, which is correlated with clinical severity of the disease (Kwak, Koo, Choi, \& Sunwoo, 2001; Nagai et al., 1996). A similar correlation has been observed in the amyotrophic lateral sclerosis disorder in which impaired glutamatergic transmission in the central nervous system is in line with the reduced mRNA expression of the metabotropic glutamate receptor 2 in PBLs (Poulopoulou et al., 2005). These and several other studies (e.g., Amidfar et al., 2017; Liu et al., 2016; Zhang et al., 2017) have convinced the researchers that PBLs may be an appropriate cellular tool to evaluate the alterations of neurotransmitter receptors in neuropsychiatric and neurological disorders and follow the results of therapeutic interventions. We have previously investigated the changes that happen at the expression level of NMDA receptor subunits in human PBLs in opioid addiction (Roozafzoon et al., 2010; Sedaghati et al., 2010). The results of the mentioned studies made us investigate whether addictive behaviors, such as playing online computer games, would also alter the expression level of NMDA receptor subunits in PBLs. Therefore, we designed this study to investigate the mRNA expression state of GluN2A, GluN2D, GluN3A, and GluN3B subunits of the NMDA receptor in PBLs of game addicts compared with control group to evaluate the usefulness of these subunits as peripheral markers in studies of addictive behaviors, including online computer game addiction.

\section{MATERIALS AND METHODS}

\section{Subjects}

Two groups of male volunteers were evaluated in the study. One group was composed of 25 computer game addicts (age: $24.3 \pm 4.4$ years old), who were selected from places or shops where people go to and play computer games. The type of online computer games was not recorded. Addiction to playing online computer games was evaluated using a modified version of Young's Internet Addiction Scale 
(YIAS). It is composed of 20 questions with 5-point Likert scale (Young, 1998). The score of a person resulted from YIAS may fall into three categories of lower than 50 , $50-70$, and $>80$. These scores are taken as non-addiction, mild grades of addiction, and severe degrees of addiction, respectively. The individuals whose scores were more than 80 were invited to participate in the study. The duration of compulsive game playing in this group was $6.9 \pm 3.1$ years. Control subjects were 26 age-matched students and staff of Tehran University with YIAS scores $<50$ (age: $25.6 \pm 3.1$ years old). There were some exclusion criteria for the study: (a) dependence to any drug of abuse (assessed by both self-declaration and urine test), such as alcohol, cocaine, amphetamine, opioids, benzodiazepines, marijuana, or barbiturates (four cases in the game-addicted group were cigarette smokers but were not dependent on nicotine as stated by the fifth edition of Diagnostic and Statistical Manual of Mental Disorders criteria); (b) consumption of any kind of medications with central nervous system effects; (c) having current infectious or inflammatory diseases, such as HCV, HBV, and HIV; (d) having current or a history of major neurological, psychiatric, endocrine, or cardiovascular disorders.

\section{PBL preparation}

An amount of 5-ml blood samples were drawn from volunteers by antecubital venipuncture in ethylenediaminetetracetic acid-containing tubes. To separate lymphocytes, total blood was placed on a cell separation medium (Histoprep/BAG, Lich, Germany) and centrifuged in a horizontal rotor with $1,200 \times g$ for $35 \mathrm{~min}$ at room temperature as mentioned in the manufacturer's protocol. The layer containing lymphocytes was then collected and washed in cold phosphate-buffered saline $(\mathrm{pH}=7.4)$ for three times. The lymphocyte separation process was done not later than $4 \mathrm{hr}$ after blood sample collection to minimize blood RNA degradation.

\section{Total RNA extraction and reverse transcription}

Total RNA was extracted from lymphocytes by RNeasy Mini Kit (Qiagen, Hilden, Germany) according to the manufacturer's protocol. The quantity of extracted RNA was measured by spectrophotometry and its purity was checked by gel electrophoresis (1\% agarose, Gibco/BRL, Grand Island, NY, USA). First-strand cDNA was synthesized using $1 \mu \mathrm{g}$ RNA in a final volume of $20 \mu \mathrm{l}$ with the QuantiTect Reverse Transcription Kit (Qigen) as mentioned in the manufacturer's protocol.

\section{Oligonucleotide primers used for real-time polymerase chain reaction $(P C R)$ amplification}

Amplification of GluN2A, GluN2D, GluN3A, and GluN3B subunits of the NMDA receptor in real-time polymerase chain reaction $(\mathrm{PCR})$ was performed with oligonucleotide primers purchased from Qiagen company primer bank. Normalization of target genes expression was achieved using the beta-actin as the housekeeping gene where its primers were also ordered from Qiagen company.

\section{Real-time PCR}

Real-time PCR reactions were performed using $2 \mu \mathrm{l}$ of the first-strand cDNA, specific primers, and Power SYBR ${ }^{\circledR}$ Green PCR Master Mix (Life Technologies, Carlsbad, CA, USA) as mentioned in the manufacturer's protocol on a StepOnePlus ${ }^{\mathrm{TM}}$ Real-Time PCR System (Applied Biosystems, USA). For each gene, the real-time PCR reaction was adjusted in such a way that a single product was amplified for each primer pair. The optimized annealing temperature of reactions was from 60 to $63{ }^{\circ} \mathrm{C}$. Observing a single peak in melting curve analysis was considered as the confirmation of the specificity of PCR products. In addition, correct length of products was validated by visualization on $2 \%$ agarose gel with ethidium bromide.

\section{Data analysis}

For all samples, a value was defined as the $\mathrm{Ct}$ of the sample, which was the number of the cycle at which the sample fluorescence reached a preset threshold. In each reaction run, a standard curve was plotted using a serial dilution of a known cDNA sample and then the Cts of the unknown samples were referred to the curve. Samples were measured in duplicate and the mean was used for further analysis. All samples were normalized against beta-actin as the housekeeping gene. The data of the study were analyzed by the REST-XL version 2 software (Pfaffl, Horgan, \& Dempfle, 2002). The software needs PCR efficiencies of the runs and the mean crossing point (CP) deviations to define and compare the relative gene expression levels and the significant differences between two groups. Real-time PCR efficiency $(E)$ is calculated as: $E=10^{[-1 / \text { slope }]}$, which is applied to a serial dilution of cDNA. The software calculates the ratio of gene expression between control and sample groups and the normalization of the target gene expression by mean of the reference gene using the following equation:

$$
\begin{aligned}
\text { Ratio }= & \left(E_{\text {target }}\right)^{\Delta \mathrm{CPtarget}(\text { Mean control-Mean sample }) /} \\
& \left(E_{\text {reference }}\right)^{\Delta \mathrm{CPreference}(\text { Mean control-Mean sample })} .
\end{aligned}
$$

The software uses the Pair-Wise Fixed Reallocation Randomization Test to calculate the significance of the results. Randomization tests are proper substitutions to parametric tests and their special advantage is making no distributional expectations about the data and being as powerful as the more standardized tests. Thus, we calculated one separate analysis (game addicted in comparison with the control group) for each target gene (GluN2A, GluN2D, GluN3A, and GluN3B subunits of the NMDA receptor) in the study. $P<.05$ was considered statistically significant and data are shown as fold differences of mean normalized expression values \pm standard error of the mean (SEM).

\section{Ethics}

The study procedures were carried out in accordance with the Declaration of Helsinki and were approved by the Institutional Ethics Committee. All subjects were informed about the study and all provided informed consent. 


\section{RESULTS}

Figure 1A demonstrates the comparison of mRNA expression level of GluN2A subunit of NMDA receptor in PBLs between online computer game addicts and control volunteers. The GluN2A subunit of NMDA receptor was downregulated in game-addicted subjects by the factor 0.84 , which was not statistically different from control group $(P>.05)$. The beta-actin expression did not differ between the groups tested (data not shown).

As shown in Figure 1B, the expression level of the GluN2D subunit of NMDA receptor increased in online game-addicted subjects and reached $1.06(P>.05)$, the amount of the control group.

Figure 1C demonstrates the mRNA expression level of the GluN3A subunit in PBLs of study groups. We observed a significant reduction in the expression of GluN3A subunit in the game-addicted group compared
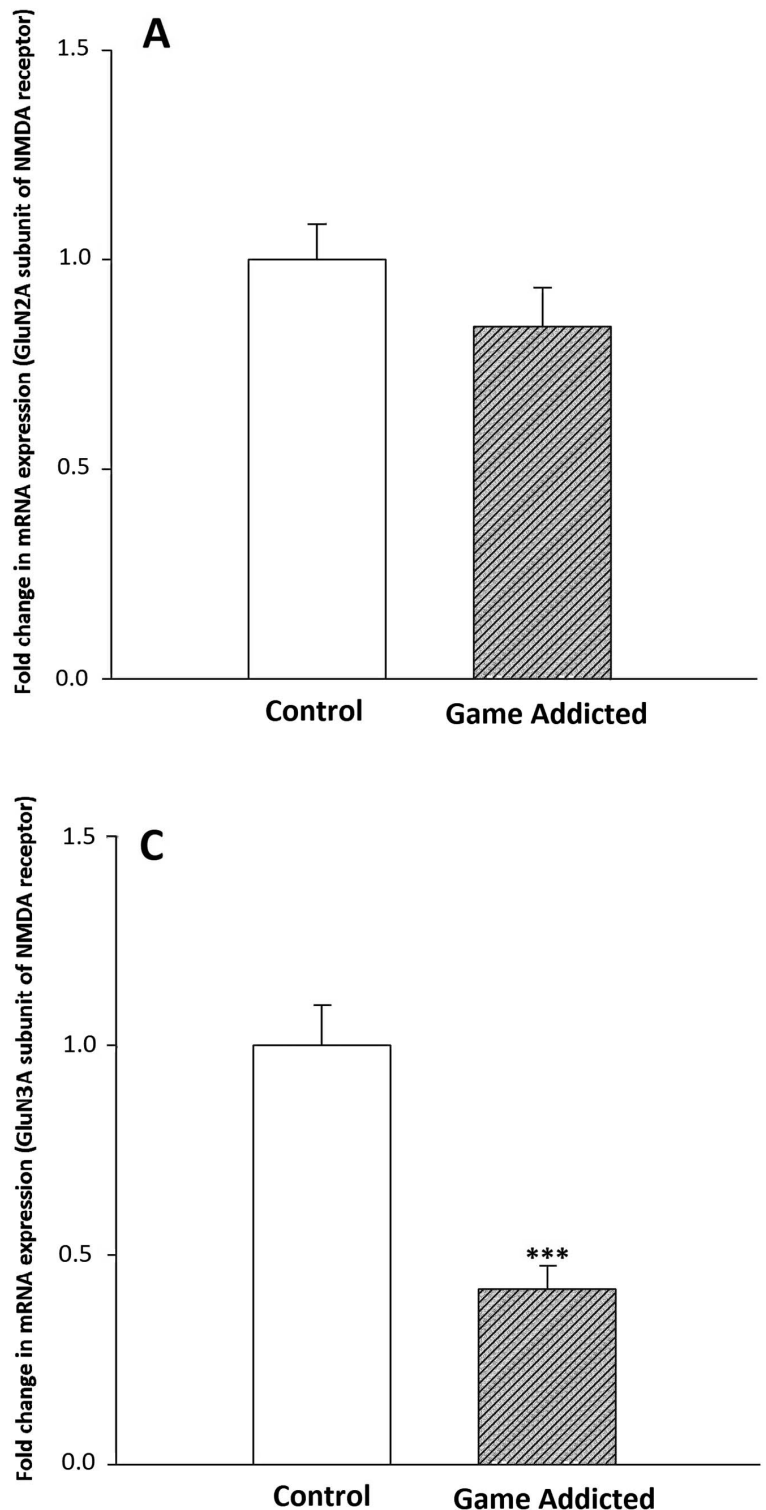

with the control subjects $(0.41$, the amount of the control group; $P<.001$ ).

As shown in Figure 1D, the expression level of the GluN3B subunit of NMDA receptor was downregulated in game-addicted subjects and reached $0.9(P>.05)$, the amount of the control group.

\section{DISCUSSION}

In recent years, preclinical and clinical studies have reported that significant overlap may exist between the neural pathways that are involved in reward-related learning in drug dependence and those that mediate non-drug behavioral addictions, such as pathological gambling, kleptomania, eating, shopping, sex, Internet, and exercise addiction (Lee et al., 2012; Olive, Cleva, Kalivas, \& Malcolm, 2012; Palaus, Marron, Viejo-Sobera, \& Redolar-Ripoll, 2017).
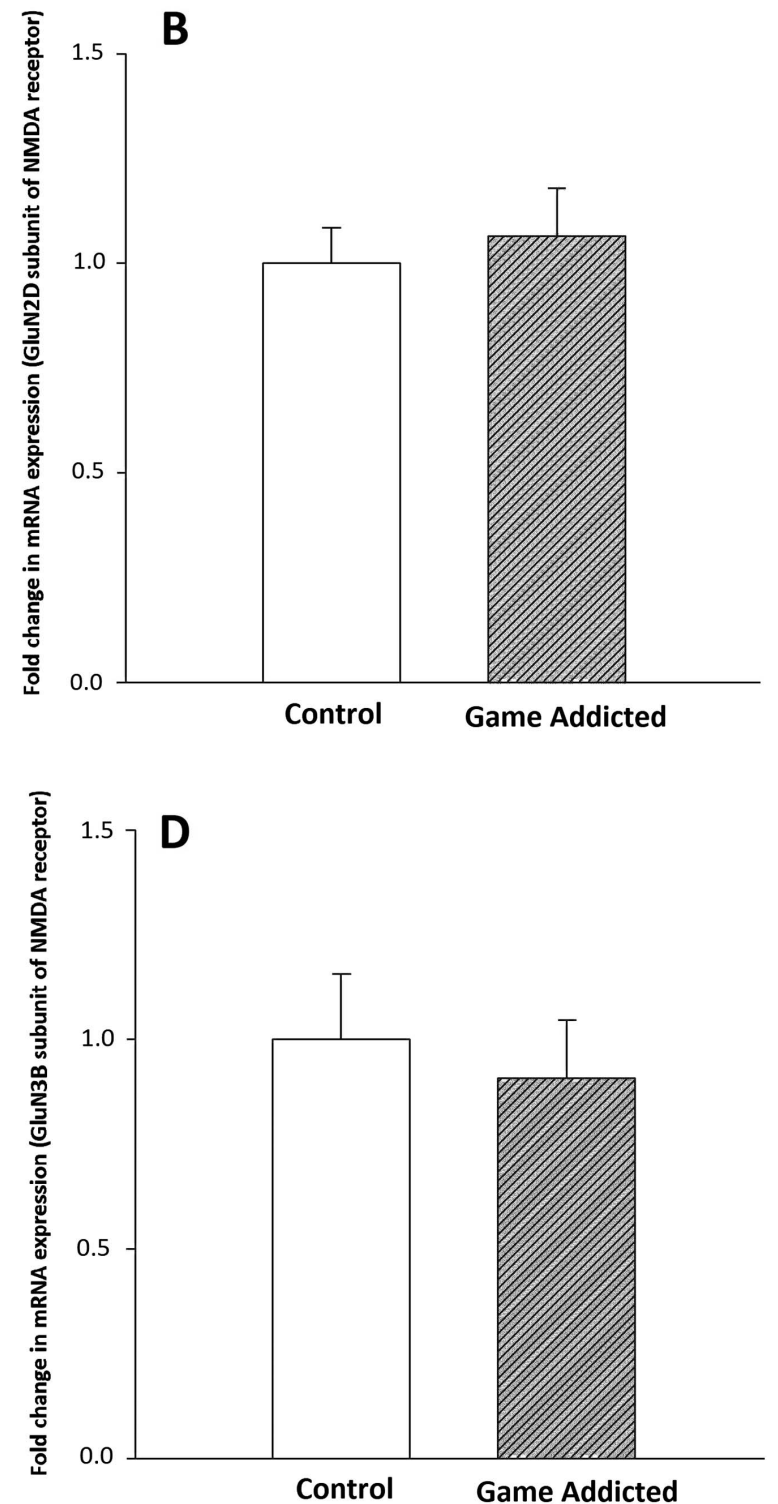

Figure 1. The mRNA expression of GluN2A (A), GluN2D (B), GluN3A (C), and GluN3B (D) subunits of NMDA receptor in PBLs of the computer game-addicted and control subjects. Bars represent fold differences of mean normalized expression values \pm SEM $(n=25$ in game-addicted and 26 in control groups). ${ }^{* * *} P<.001$ from the control group 
However, evidence confirming the above statement is limited. It is now believed that glutamatergic transmission has a key role in the process of addiction development and it is considered as a possible novel target for pharmacological treatment of drug and behavioral addictions (Márquez et al., 2017). The NMDA receptor as a tetramer-structured ionotropic glutamate receptor is significantly involved in many neuronal and organizational brain functions, such as fast excitatory transmission, synaptic plasticity, learning, and memory (Glasgow et al., 2015). The receptor is composed of GluN1 subunit together with subunits of GluN2 and GluN3 families. Although the subunits have distinct patterns of expression in the brain, they are highly concentrated in cerebral cortex and hippocampus, which are responsible for memory formation and higher levels of cognition (Law et al., 2003).

NMDA receptors are critically involved in addiction since blocking these receptors with NMDA antagonists abolishes the rewarding or reinforcing characteristics of drugs of abuse, such as cocaine and morphine (Ma, Cepeda, \& Cui, 2009), and inhibits addictive behaviors, such as pathological gambling (Grant, Chamberlain, Odlaug, Potenza, \& Kim, 2010).

Preclinical studies have shown that the expression level of NMDA receptor subunits alters in addiction (Jin et al., 2014a; Nagy, 2008; Zhu et al., 1999). However, it is not possible to investigate the expression changes of NMDA receptor subunits directly in the living brain of drug- or behavioral addicted people. Nonetheless, there is a hypothesis called "peripheral marker hypothesis" or "mirror hypothesis" stating that alterations in the levels of expression of neurotransmitter receptors in the brain may be similar to their changes in PBLs. The hypothesis has been widely investigated about dopaminergic receptors. For example, it has been shown that the expression level of D5 dopamine receptor in PBLs is increased in patients suffering from Tourette's syndrome and this increase has a positive correlation with the severity of compulsive symptoms of the syndrome (Ferrari et al., 2008). Conversely, in Parkinson's disease, evaluation of the expression level of dopamine receptors in PBLs has shown a dramatic decrease compared with healthy subjects, which is linearly correlated with the patients' degree of disability (Nagai et al., 1996). In schizophrenia, it has been reported that the upregulated state of dopamine receptors in PBLs of patients (Bondy, Ackenheil, Elbers, \& Frohler, 1985; Ilani et al., 2001), which is a reflection of the upregulated state of dopamine receptors in the brain, is directly correlated with the severity of psychiatric symptoms and is relatively reduced by antipsychotic medications (Kwak et al., 2001; Vogel et al., 2004). Thus, it seems that PBLs may act as an available and easily achievable tool to investigate mechanisms of neural diseases and the way that drugs may be helpful in the treatment of them. Furthermore, evaluation of the state of PBLs may help to follow the effectiveness of medical and non-medical therapies in brain disorders.

Although glutamate receptors and especially NMDA receptors are widely involved in many brain diseases, peripheral marker hypothesis has not been much studied about these receptors. It has been shown previously that glutamate receptors like many other neurotransmitter receptors may be found on immune cells, such as lymphocytes and thymocytes (Boldyrev et al., 2004; Ganor, Besser, Ben-Zakay, Unger, \& Levite, 2003; Kvaratskhelia et al., 2009; Storto et al., 2000), natural killer cells (Kuo et al., 2001), and macrophages (Dickman, Youssef, Mathew, \& Said, 2004). Some kind of immune cell functions, such as proliferation, growth, and death, seems to be mediated by activation of glutamate receptors in immune cells (Lombardi, Dianzani, Miglio, Canonico, \& Fantozzi, 2001; Mashkina et al., 2007). The existence of GluN1 and GluN2 subunits of the NMDA receptor in human PBLs has been reported before (Bhandage et al., 2017; Miglio et al., 2005). In addition, we have found in our previous studies that GluN3A and GluN3B subunits of NMDA receptor are also expressed in human PBLs (Roozafzoon et al., 2010; Sedaghati et al., 2010). To our knowledge, this is the first report concerning the mRNA expression of GluN2A, GluN2D, and GluN3 subunits of the NMDA receptor in PBLs of online computer game addicts.

GluN2A subunit of NMDA receptors is widely expressed in different parts of the human brain (Kew \& Kemp, 2005) and its existence in the structure of NMDA receptor seems to be necessary for drug addiction development. This can be shown by lack of morphine-induced place preference in GluN2A mutant mice (Miyamoto et al., 2004). GluN2D is largely expressed in midbrain sites (Laurie, Bartke, Schoepfer, Naujoks, \& Seeburg, 1997). In addition, the subunit may be found in murine hippocampus, thalamus, and cortex (Dunah, Luo, Wang, Yasuda, \& Wolfe, 1998). It has been shown that incorporation of the GluN2D subunit in NMDA receptor structure significantly increases the excitatory current of the ion channel (Thompson, Drewery, Atkins, Stephenson, \& Chazot, 2002). Our data showed that the expression level of GluN2A and GluN2D subunits of the NMDA receptor in PBLs of online computer game addicts is not statistically different from the control group. This is similar to our previous findings in opioid-addicted subjects whose mRNA expression levels of these two subunits in PBLs were the same as the non-addicted individuals (Roozafzoon et al., 2010; Sedaghati et al., 2010). According to the peripheral marker hypothesis, it may be assumed that the mRNA expression of GluN2A and GluN2D subunits in the brain is not changed by addiction to a behavior, such as computer game playing. In this regard, previous animal studies have shown that the expression level of GluN2 subunits of NMDA receptors is not altered in many parts of the rat brain, such as the nucleus accumbens, hippocampus, frontal cortex, locus coeruleus, and amygdale, after chronic morphine administration (Hemby, 2004; Zhu et al., 1999). However, postmortem studies have shown that GluN2B subunit is increased in the hippocampus in alcoholics and cocaine addicts, whereas GluN2D is increased in alcoholics and decreased in cocaine addicts (Enoch et al., 2014; Jin et al., 2014b). Although the peripheral marker hypothesis may suggest the existence of similarity in the pattern of gene expression between lymphocytes and the brain, however, it cannot be confirmed until the transcriptional studies of behavioral addictions in the human brain are completed in the future.

It has been proven in previous studies that incorporation of GluN3 subunits of the NMDA receptor, including 
GluN3A and GluN3B in the structure of receptor tetramer, reduces the NMDA receptor function and excitatory current flow in cells by decreasing the permeability of the receptor channel of calcium (McClymont, Harris, \& Mellor, 2012). GluN3A is extensively expressed in human brain areas including the cerebral cortex and subcortical regions, such as the mesolimbic system (Mueller \& Meador-Woodruff, 2005; Nilsson et al., 2007). However, the expression pattern of GluN3B is not as wide as GluN3A subunit. The former subunit may be found in sites, such as the brainstem, motor neurons in the spinal cord (Matsuda, Kamiya, Matsuda, \& Yuzaki, 2002; Nishi, Hinds, Lu, Kawata, \& Hayashi, 2001), hippocampus, and adjacent neocortex (Bendel, Meijer, Hurd, \& von Euler, 2005).

The present data show that the expression level of GluN3A in PBLs of online computer game addicts is significantly lower than the control group. In our previous studies, we found a similar decrease in GluN3A mRNA expression in PBLs of abstinent former opioid-addicted subjects, which was returned to normal levels in current opioid abusers (Roozafzoon et al., 2010). Thus, it seems that there may be a basic deficiency in the expression of GluN3A subunit in people who are vulnerable to addiction and this deficiency is recovered with opioid abuse, but not with the addictive performance of behaviors, such as computer game playing. This may explain why many game addicts are also dependent on drugs of abuse. According to the peripheral marker hypothesis, if the expression of GluN3A subunit is also reduced in these people's brains, then it would predict the increased activity of GluN3A-containing NMDA receptors in this organ. Increased activity of NMDA receptor in some areas of the brain reward pathway seems to be a neuroadaptation that occurs after repeated performance of behaviors that are closely followed by rewards (Pettorruso et al., 2014). This may explain why treatment with memantine, an NMDA receptor antagonist, is associated with amelioration of symptoms and craving in behavioral addictions, such as pathological gambling (Achab \& Khazaal, 2011). It has been claimed that the effect of the drug is mediated by antagonizing of NMDA receptors in the striatum (Grant et al., 2010). In addition, some other antiglutamatergic drugs, such as amantadine and topiramate, have also been introduced as drugs that are effective in the treatment of pathological gambling and other addictive behaviors, such as eating disorders (Kalivas, 2009; Pettorruso et al., 2012, 2014). Our data may propose the downregulation of GluN3A subunit of NMDA receptor as a possible mechanism for increased activity of NMDA receptors in drug and behavioral addictions. Furthermore, preclinical studies have shown that rodents will self-administer many NMDA receptor antagonists directly into different parts of the reward pathway, such as the nucleus accumbens, PFC (Carlezon \& Wise, 1996), and ventral tegmental area (David, Durkin, \& Cazala, 1998), to experience reward. Thus, downregulation of the GluN3A subunit in online computer game addicts by increasing the activity of NMDA receptors may result in a reward deficiency state that makes these people motivated for seeking game playing-related pleasure and reward.

Our results also showed that the expression level of GluN3B subunit as the other member of NMDA receptor suppressant subunits is not statistically different between game addicts and control subjects. This is not consistent with our previous findings in opioid addiction since the expression of the subunit was increased in opioid addicts compared with normal subjects (Sedaghati et al., 2010). This variation shows that despite common etiopathological pathways between behavioral addictions and drug addiction (Criscitelli \& Avena, 2016), some neurobiological mechanisms may differ in various types of addiction. Further studies are needed to be performed in the future to clarify these differences more precisely. For example, evaluation of the state of GluN3B subunit expression during addiction development of the brain may be very helpful in this way. In addition, it would be informative to evaluate the expression level of other subunits of the NMDA receptor in drug and behavioral addictions, which could help to further discover the mechanism and pathways of addiction.

\section{CONCLUSIONS}

This study shows that online computer game addiction similar to drug addiction may not change the transcriptional level of GluN2A and GluN2D subunits of the NMDA receptor. However, our data showed that some mechanistic differences seem to exist between online computer game addiction and drug abuse when evaluating the GluN3 family of NMDA receptor subunits. Unlike with our previous findings of drug dependence, present data showed that the mRNA expression level of GluN3A and GluN3B subunits in PBLs of online computer game addicts is reduced and unchanged, respectively, in comparison with control individuals. However, it is not clear whether the reduced level of GluN3A in PBLs of game addicts results from repeated and addictive performance of this behavior or a preexisting deficiency in the expression of this subunit in addiction-prone subjects. Despite this uncertainty, at least it can be claimed that the observed data of this study and similar studies on behavioral addictions are free of the confounding supraphysiological effects of drugs of abuse, which may be confusing in drug addiction studies. Our results may also support the idea that manipulation of the glutamatergic system with special focus on GluN3A subunit of NMDA receptors is an effective approach to the treatment of behavioral addictions.

\section{Funding sources: None.}

Authors' contribution: NV contributed to study concept and design. M-SS-S contributed in the performance of experiments. SZZ and SN contributed in analysis and interpretation of data. BA and SMM contributed to statistical analysis. $\mathrm{NV}$ and MRZ contributed in study supervision. NV and SMM contributed to writing and revision of the paper. All authors have access to data in the study and take responsibility for the integrity of the data and the accuracy of the data analysis. 
Conflict of interest: The authors declare no conflict of interest.

\section{REFERENCES}

Achab, S., \& Khazaal, Y. (2011). Psychopharmacological treatment in pathological gambling: A critical review. Current Pharmaceutical Design, 17(14), 1389-1395. doi:10.2174/ 138161211796150774

Amidfar, M., Kim, Y. K., Colic, L., Arbabi, M., Mobaraki, G., Hassanzadeh, G., \& Walter, M. (2017). Increased levels of 5HT2A receptor mRNA expression in peripheral blood mononuclear cells of patients with major depression: Correlations with severity and duration of illness. Nordic Journal of Psychiatry, 71(4), 282-288. doi:10.1080/08039488. 2016.1276624

Bajo, M., Crawford, E. F., Roberto, M., Madamba, S. G., \& Siggins, G. R. (2006). Chronic morphine treatment alters expression of N-methyl-D-aspartate receptor subunits in the extended amygdala. Journal of Neuroscience Research, 83(4), 532-537. doi:10.1002/jnr.20756

Bendel, O., Meijer, B., Hurd, Y., \& von Euler, G. (2005). Cloning and expression of the human NMDA receptor subunit NR3B in the adult human hippocampus. Neuroscience Letters, 377(1), 31-36. doi:10.1016/j.neulet.2004.11.064

Bhandage, A. K., Jin, Z., Hellgren, C., Korol, S. V., Nowak, K., Williamsson, L., Sundström-Poromaa, I., \& Birnir, B. (2017). AMPA, NMDA and kainate glutamate receptor subunits are expressed in human peripheral blood mononuclear cells (PBMCs) where the expression of GluK4 is altered by pregnancy and GluN2D by depression in pregnant women. Journal of Neuroimmunology, 305, 51-58. doi:10.1016/j.jneuroim. 2017.01.013

Biermann, T., Bonsch, D., Reulbach, U., Kornhuber, J., \& Bleich, S. (2007). Dopamine and N-methyl-D-aspartate receptor expression in peripheral blood of patients undergoing alcohol withdrawal. Journal of Neural Transmission (Vienna), 114(8), 1081-1084. doi:10.1007/s00702-007-0661-4

Boldyrev, A. A., Kazey, V. I., Leinsoo, T. A., Mashkina, A. P., Tyulina, O. V., Johnson, P., Tuneva, J. O., Chittur, S., \& Carpenter, D. O. (2004). Rodent lymphocytes express functionally active glutamate receptors. Biochemical and Biophysical Research Communications, 324(1), 133-139. doi:10. 1016/j.bbrc.2004.09.019

Bondy, B., Ackenheil, M., Elbers, R., \& Frohler, M. (1985). Binding of 3H-spiperone to human lymphocytes: A biological marker in schizophrenia? Psychiatry Research, 15(1), 41-48. doi:10.1016/0165-1781(85)90038-1

Carlezon, W.A., Jr., \& Wise, R.A. (1996). Rewarding actions of phencyclidine and related drugs in nucleus accumbens shell and frontal cortex. Journal of Neuroscience, 16(9), 3112-3122. doi:10.1523/JNEUROSCI.16-09-03112.1996

Carlsson, A., Waters, N., \& Carlsson, M. L. (1999). Neurotransmitter interactions in schizophrenia-therapeutic implications. European Archives of Psychiatry and Clinical Neuroscience, 249(Suppl. 4), S37-S43. doi:10.1007/PL00014183

Cavara, N.A., \& Hollmann, M. (2008). Shuffling the deck anew: How NR3 tweaks NMDA receptor function. Molecular Neurobiology, 38(1), 16-26. doi:10.1007/s12035-008-8029-9
Cooper, S., Robison, A. J., \& Mazei-Robison, M. S. (2017). Reward circuitry in addiction. Neurotherapeutics, 14(3), 687-697. doi:10.1007/s13311-017-0525-z

Criscitelli, K., \& Avena, N. M. (2016). The neurobiological and behavioral overlaps of nicotine and food addiction. Preventive Medicine, 92, 82-89. doi:10.1016/j.ypmed.2016. 08.009

David, V., Durkin, T. P., \& Cazala, P. (1998). Rewarding effects elicited by the microinjection of either AMPA or NMDA glutamatergic antagonists into the ventral tegmental area revealed by an intracranial self-administration paradigm in mice. European Journal of Neuroscience, 10(4), 1394-1402. doi:10.1046/j.1460-9568.1998.00150.x

Dickman, K. G., Youssef, J. G., Mathew, S. M., \& Said, S. I. (2004). Ionotropic glutamate receptors in lungs and airways: Molecular basis for glutamate toxicity. American Journal of Respiratory Cell and Molecular Biology, 30(2), 139-144. doi:10.1165/rcmb.2003-0177OC

Dunah, A. W., Luo, J., Wang, Y. H., Yasuda, R. P., \& Wolfe, B. B. (1998). Subunit composition of N-methyl-D-aspartate receptors in the central nervous system that contain the NR2D subunit. Molecular Pharmacology, 53(3), 429-437. doi:10.1124/ mol.53.3.429

Enoch, M. A., Rosser, A. A., Zhou, Z., Mash, D. C., Yuan, Q., \& Goldman, D. (2014). Expression of glutamatergic genes in healthy humans across 16 brain regions; altered expression in the hippocampus after chronic exposure to alcohol or cocaine. Genes Brain and Behavior, 13(8), 758-768. doi:10.1111/ gbb. 12179

Ferrari, M., Termine, C., Franciotta, D., Castiglioni, E., Pagani, A., Lanzi, G., Marino, F., Lecchini, S., Cosentino, M., \& Balottin, U. (2008). Dopaminergic receptor D5 mRNA expression is increased in circulating lymphocytes of Tourette syndrome patients. Journal of Psychiatric Research, 43(1), 24-29. doi:10.1016/j.jpsychires.2008.01.014

Floyd, D. W., Jung, K. Y., \& McCool, B. A. (2003) Chronic ethanol ingestion facilitates $\mathrm{N}$-methyl-D-aspartate receptor function and expression in rat lateral/basolateral amygdala neurons. Journal of Pharmacology and Experimental Therapeutics, 307(3), 1020-1029. doi:10.1124/jpet.103.057505

Ganor, Y., Besser, M., Ben-Zakay, N., Unger, T., \& Levite, M. (2003). Human T cells express a functional ionotropic glutamate receptor GluR3, and glutamate by itself triggers integrinmediated adhesion to laminin and fibronectin and chemotactic migration. Journal of Immunology, 170(8), 4362-4372. doi:10.4049/jimmunol.170.8.4362

Glasgow, N. G., Siegler Retchless, B., \& Johnson, J. W. (2015). Molecular bases of NMDA receptor subtype-dependent properties. Journal of Physiology, 593(1), 83-95. doi:10.1113/ jphysiol.2014.273763

Grant, J. E., Chamberlain, S. R., Odlaug, B. L., Potenza, M. N., \& Kim, S. W. (2010). Memantine shows promise in reducing gambling severity and cognitive inflexibility in pathological gambling: A pilot study. Psychopharmacology (Berl), 212(4), 603-612. doi:10.1007/s00213-010-1994-5

Hemby, S. E. (2004). Morphine-induced alterations in gene expression of calbindin immunopositive neurons in nucleus accumbens shell and core. Neuroscience, 126(3), 689-703. doi:10.1016/j.neuroscience.2004.01.056

Ilani, T., Ben-Shachar, D., Strous, R. D., Mazor, M., Sheinkman, A., Kotler, M., \& Fuchs, S. (2001). A peripheral marker for 
schizophrenia: Increased levels of D3 dopamine receptor mRNA in blood lymphocytes. Proceedings of the National Academy of Sciences the United States of America, 98(2), 625-628. doi:10.1073/pnas.98.2.625

Jin, Z., Bhandage, A. K., Bazov, I., Kononenko, O., Bakalkin, G., Korpi, E. R., \& Birnir, B. (2014a). Expression of specific ionotropic glutamate and GABA-A receptor subunits is decreased in central amygdala of alcoholics. Frontiers in Cellular Neuroscience, 8, 288. doi:10.3389/fncel.2014.00288

Jin, Z., Bhandage, A. K., Bazov, I., Kononenko, O., Bakalkin, G., Korpi, E. R., \& Birnir, B. (2014b). Selective increases of AMPA, NMDA, and kainate receptor subunit mRNAs in the hippocampus and orbitofrontal cortex but not in prefrontal cortex of human alcoholics. Frontiers in Cellular Neuroscience, 8, 1-10. doi:10.3389/fncel.2014.00011

Jorgenson, A. G., Hsiao, R. C., \& Yen, C. F. (2016). Internet addiction and other behavioral addictions. Child and Adolescent Psychiatric Clinics of North America, 25(3), 509-520. doi:10.1016/j.chc.2016.03.004

Kalivas, P. W. (2009). The glutamate homeostasis hypothesis of addiction. Nature Reviews Neuroscience, 10(8), 561-572. doi:10.1038/nrn2515

Kew, J. N., \& Kemp, J. A. (2005). Ionotropic and metabotropic glutamate receptor structure and pharmacology. Psychopharmacology (Berl), 179(1), 4-29. doi:10.1007/s00213-005-2200-Z

Kuo, J. S., Chen, S. F., Huang, H. J., Yang, C. S., Tsai, P. J., \& Hsueh, C. M. (2001). The involvement of glutamate in recall of the conditioned NK cell response. Journal of Neuroimmunology, 118(2), 245-255. doi:10.1016/S01655728(01)00340-X

Kvaratskhelia, E., Maisuradze, E., Dabrundashvili, N. G., Natsvlishvili, N., Zhuravliova, E., \& Mikeladze, D. G. (2009). N-methyl-D-aspartate and sigma-ligands change the production of interleukins 8 and 10 in lymphocytes through modulation of the NMDA glutamate receptor. Neuroimmunomodulation, 16(3), 201-207. doi:10.1159/000204234

Kwak, Y. T., Koo, M. S., Choi, C. H., \& Sunwoo, I. (2001). Change of dopamine receptor mRNA expression in lymphocyte of schizophrenic patients. BMC Medical Genetics, 2(1), 3. doi:10.1186/1471-2350-2-3

Laurie, D. J., Bartke, I., Schoepfer, R., Naujoks, K., \& Seeburg, P. H. (1997). Regional, developmental and interspecies expression of the four NMDAR2 subunits, examined using monoclonal antibodies. Brain Research. Molecular Brain Research, 51(1-2), 23-32. doi:10.1016/S0169-328X(97) 00206-4

Law, A. J., Weickert, C. S., Webster, M. J., Herman, M. M., Kleinman, J. E., \& Harrison, P. J. (2003). Expression of NMDA receptor NR1, NR2A and NR2B subunit mRNAs during development of the human hippocampal formation. European Journal of Neuroscience, 18(5), 1197-1205. doi:10.1046/j.1460-9568.2003.02850.x

Lee, H. W., Choi, J. S., Shin, Y. C., Lee, J. Y., Jung, H. Y., \& Kwon, J. S. (2012). Impulsivity in Internet addiction: A comparison with pathological gambling. Cyberpsychology, Behavior, and Social Networking, 15(7), 373-377. doi:10.1089/ cyber.2012.0063

Liu, J., Prell, T., Stubendorff, B., Keiner, S., Ringer, T., Gunkel, A., Tadic, V., Goldhammer, N., Malci, A., Witte, O. W., \& Grosskreutz, J. (2016). Down-regulation of purinergic P2X7 receptor expression and intracellular calcium dysregulation in peripheral blood mononuclear cells of patients with amyotrophic lateral sclerosis. Neuroscience Letters, 630, 77-83. doi:10.1016/j.neulet.2016.07.039

Lombardi, G., Dianzani, C., Miglio, G., Canonico, P.L., \& Fantozzi, R. (2001). Characterization of ionotropic glutamate receptors in human lymphocytes. British Journal of Pharmacology, 133(6), 936-944. doi:10.1038/sj.bjp.0704134

Ma, Y. Y., Cepeda, C., \& Cui, C. L. (2009). The role of striatal NMDA receptors in drug addiction. International Review of Neurobiology, 89, 131-146. doi:10.1016/S0074-7742(09) 89006-5

Márquez, J., Campos-Sandoval, J. A., Peñalver, A., Matés, J. M., Segura, J. A., Blanco, E., Alonso, F. J., \& de Fonseca, F. R. (2017). Glutamate and brain glutaminases in drug addiction. Neurochemical Research, 42(3), 846-857. doi:10.1007/s11064016-2137-0

Mashkina, A. P., Tyulina, O. V., Solovyova, T. I., Kovalenko, E. I., Kanevski, L. M., \& Johnson, P., \& Boldyrev, A. A. (2007). The excitotoxic effect of NMDA on human lymphocyte immune function. Neurochemistry International, 51(6-7), 356360. doi:10.1016/j.neuint.2007.04.009

Matsuda, K., Kamiya, Y., Matsuda, S., \& Yuzaki, M. (2002). Cloning and characterization of a novel NMDA receptor subunit NR3B: A dominant subunit that reduces calcium permeability. Brain Research. Molecular Brain Research, 100(1-2), 43-52. doi:10.1016/S0169-328X(02)00173-0

McClymont, D. W., Harris, J., \& Mellor, I. R. (2012). Openchannel blockade is less effective on GluN3B than GluN3A subunit-containing NMDA receptors. European Journal of Pharmacology, 686(1-3), 22-31. doi:10.1016/j.ejphar.2012. 04.036

Miglio, G., Varsaldi, F., \& Lombardi, G. (2005). Human T lymphocytes express N-methyl-D-aspartate receptors functionally active in controlling $\mathrm{T}$ cell activation. Biochemical and Biophysical Research Communications, 338(4), 1875-1883. doi:10.1016/j.bbrc.2005.10.164

Miyamoto, Y., Yamada, K., Nagai, T., Mori, H., Mishina, M., Furukawa, H., Noda, Y., \& Nabeshima, T. (2004). Behavioural adaptations to addictive drugs in mice lacking the NMDA receptor epsilon1 subunit. European Journal of Neuroscience, 19(1), 151-158. doi:10.1111/j.1460-9568.2004.03086.x

Mueller, H. T., \& Meador-Woodruff, J. H. (2005). Distribution of the NMDA receptor NR3A subunit in the adult pig-tail macaque brain. Journal of Chemical Neuroanatomy, 29(3), 157-172. doi:10.1016/j.jchemneu.2004.11.002

Nagai, Y., Ueno, S., Saeki, Y., Soga, F., Hirano, M., \& Yanagihara, T. (1996). Decrease of the D3 dopamine receptor mRNA expression in lymphocytes from patients with Parkinson's disease. Neurology, 46(3), 791-795. doi:10.1212/WNL. 46.3 .791

Nagy, J. (2008). Alcohol related changes in regulation of NMDA receptor functions. Current Neuropharmacology, 6(1), 39-54. doi:10.2174/157015908783769662

Nilsson, A., Eriksson, M., Muly, E. C., Akesson, E., Samuelsson, E. B., Bogdanovic, N., Benedikz, E., \& Sundstrom, E. (2007). Analysis of NR3A receptor subunits in human native NMDA receptors. Brain Research, 1186, 102-112. doi:10.1016/j. brainres.2007.09.008

Nishi, M., Hinds, H., Lu, H.P., Kawata, M., \& Hayashi, Y. (2001). Motoneuron-specific expression of NR3B, a novel NMDAtype glutamate receptor subunit that works in a dominant- 
negative manner. Journal of Neuroscience, 21(23), RC185. doi:10.1523/JNEUROSCI.21-23-j0003.2001

Olive, M. F., Cleva, R. M., Kalivas, P. W., \& Malcolm, R. J. (2012). Glutamatergic medications for the treatment of drug and behavioral addictions. Pharmacology, Biochemistry, and Behavior, 100(4), 801-810. doi:10.1016/j.pbb.2011.04.015

Palaus, M., Marron, E. M., Viejo-Sobera, R., \& Redolar-Ripoll, D. (2017). Neural basis of video gaming: A systematic review. Frontiers in Human Neuroscience, 11, 248. doi:10.3389/ fnhum.2017.00248

Pérez-Otaño, I., Larsen, R. S., \& Wesseling, J. F. (2016). Emerging roles of GluN3-containing NMDA receptors in the CNS. Nature Reviews Neuroscience, 17(10), 623-635. doi:10. 1038/nrn.2016.92

Pettorruso, M., De Risio, L., Martinotti, G., Di Nicola, M., Ruggeri, F., Conte, G., Di Giannantonio, M., \& Janiri, L. (2014). Targeting the glutamatergic system to treat pathological gambling: Current evidence and future perspectives. BioMed Research International, 2014, 1-11. doi:10.1155/ 2014/109786

Pettorruso, M., Martinotti, G., Di Nicola, M., Onofrj, M., Di Giannantonio, M., Conte, G., \& Janiri, L. (2012). Amantadine in the treatment of pathological gambling: A case report. Frontiers in Psychiatry, 3, 102. doi:10.3389/fpsyt.2012.00102

Pfaffl, M. W., Horgan, G. W., \& Dempfle, L. (2002). Relative expression software tool (REST) for group-wise comparison and statistical analysis of relative expression results in real-time PCR. Nucleic Acids Research, 30(9), e36. doi:10.1093/nar/ 30.9.e36

Pistillo, F., Fasoli, F., Moretti, M., McClure-Begley, T., Zoli, M., Marks, M. J., \& Gotti, C. (2016). Chronic nicotine and withdrawal affect glutamatergic but not nicotinic receptor expression in the mesocorticolimbic pathway in a regionspecific manner. Pharmacology Research, 103, 167-176. doi:10.1016/j.phrs.2015.11.016

Poulopoulou, C., Davaki, P., Koliaraki, V., Kolovou, D., Markakis, I., \& Vassilopoulos, D. (2005). Reduced expression of metabotropic glutamate receptor 2mRNA in T cells of ALS patients. Annals of Neurology, 58(6), 946-949. doi:10.1002/ana.20675

Roozafzoon, R., Goodarzi, A., Vousooghi, N., Sedaghati, M., Yaghmaei, P., \& Zarrindast, M. R. (2010). Expression of NMDA receptor subunits in human peripheral blood lymphocytes in opioid addiction. European Journal of Pharmacology, 638(1-3), 29-32. doi:10.1016/j.ejphar.2010.04.017

Sedaghati, M., Vousooghi, N., Goodarzi, A., Yaghmaei, P., Mokri, A., \& Zarrindast, M. R. (2010). Expression of NR3B but not NR2D subunit of NMDA receptor in human blood lymphocytes can serve as a suitable peripheral marker for opioid addiction studies. European Journal of Pharmacology, 633(1-3), 50-54. doi:10.1016/j.ejphar.2010.02.007

Spencer, S., Scofield, M., \& Kalivas, P.W. (2016). The good and bad news about glutamate in drug addiction. Journal of Psychopharmacology, 30(11), 1095-1098. doi:10.1177/0269 881116655248

Storto, M., de Grazia, U., Battaglia, G., Felli, M. P., Maroder, M., Gulino, A., Ragona, G., Nicoletti, F., Screpanti, I., Frati, L., \&
Calogero, A. (2000). Expression of metabotropic glutamate receptors in murine thymocytes and thymic stromal cells. Journal of Neuroimmunology, 109(2), 112-120. doi:10.1016/ S0165-5728(00)00269-1

Thompson, C. L., Drewery, D. L., Atkins, H. D., Stephenson, F. A., \& Chazot, P. L. (2002). Immunohistochemical localization of $\mathrm{N}$-methyl-D-aspartate receptor subunits in the adult murine hippocampal formation: Evidence for a unique role of the NR2D subunit. Brain Research. Molecular Brain Research, 102(1-2), 55-61. doi:10.1016/S0169-328X(02)00183-3

Turchan, J., Maj, M., \& Przewlocka, B. (2003). The effect of drugs of abuse on NMDAR1 receptor expression in the rat limbic system. Drug and Alcohol Dependence, 72(2), 193-196. doi:10.1016/S0376-8716(03)00193-5

Tzschentke, T. M., \& Schmidt, W. J. (2003). Glutamatergic mechanisms in addiction. Molecular Psychiatry, 8(4), 373-382. doi:10.1038/sj.mp.4001269

Ustinavičienè, R., Škèmienė, L., Lukšienè, D., Radišauskas, R., Kalinienè, G., \& Vasilavičius, P. (2016). Problematic computer game use as expression of Internet addiction and its association with self-rated health in the Lithuanian adolescent population. Medicina (Kaunas), 52(3), 199-204. doi:10.1016/j.medici. 2016.04.002

Vogel, M., Pfeifer, S., Schaub, R. T., Grabe, H. J., Barnow, S., Freyberger, H. J., \& Cascorbi, I. (2004). Decreased levels of dopamine D3 receptor mRNA in schizophrenic and bipolar patients. Neuropsychobiology, 50(4), 305-310. doi:10.1159/ 000080958

Young, K. S. (1998). Internet addiction: The emergence of a new clinical disorder. CyberPsychology \& Behavior, 1(3), 237244. doi:10.1089/cpb.1998.1.237

Zhang, Y., Zhang, Y., Li, H., Jia, X., Zhang, X., Xia, Y., Wang, Y., Fu, L., Xiao, C., \& Geng, D. (2017). Increased expression of P2X7 receptor in peripheral blood mononuclear cells correlates with clinical severity and serum levels of Th17-related cytokines in patients with myasthenia gravis. Clinical Neurology and Neurosurgery, 157, 88-94. doi:10.1016/j.clineuro. 2017.04.012

Zhu, H., Brodsky, M., Gorman, A. L., \& Inturrisi, C. E. (2003). Region-specific changes in NMDA receptor mRNA induced by chronic morphine treatment are prevented by the co-administration of the competitive NMDA receptor antagonist LY274614. Brain Research. Molecular Brain Research, 114(2), 154-162. doi:10.1016/S0169-328X(03)00170-0

Zhu, H., Jang, C. G., Ma, T., Oh, S., Rockhold, R. W., \& Ho, I. K. (1999). Region specific expression of NMDA receptor NR1 subunit mRNA in hypothalamus and pons following chronic morphine treatment. European Journal of Pharmacology, 365(1), 47-54. doi:10.1016/S0014-2999 (98)00861-9

Zvara, A., Szekeres, G., Janka, Z., Kelemen, J. Z., Cimmer, C., Sántha, M., \& Puskás, L. G. (2005). Over-expression of dopamine D2 receptor and inwardly rectifying potassium channel genes in drug-naive schizophrenic peripheral blood lymphocytes as potential diagnostic markers. Disease Markers, 21(2), 61-69. doi:10.1155/2005/275318 